\title{
Control of heterotrophic prokaryotic abundance and growth rate in hypersaline planktonic environments
}

\author{
Josep M. Gasol ${ }^{1, *}$, Emilio O. Casamayor ${ }^{2}$, Ian Joint ${ }^{3}$, Kristine Garde ${ }^{4}$, \\ Kim Gustavson ${ }^{4}$, Susana Benlloch ${ }^{5,6}$, Beatriz Díez ${ }^{1,7}$, Michael Schauer $^{1,8}$, \\ Ramon Massana ${ }^{1}$, Carlos Pedrós-Alió ${ }^{1}$ \\ ${ }^{1}$ Departament de Biología Marina i Oceanografia, Institut de Ciències del Mar-CMIMA, CSIC, \\ Passeig Marítim de la Barceloneta 39-47, 08009 Barcelona, Catalunya, Spain \\ ${ }^{2}$ Unitat de Limnologia-Departament de Biogeoquímica Aquàtica, Centre d'Estudis Avançats de Blanes, CSIC, 17300 Blanes, \\ Catalunya, Spain \\ ${ }^{3}$ Plymouth Marine Laboratory, Prospect Place, The Hoe, Plymouth PL1 3DH, UK \\ ${ }^{4}$ DHI Water and Environment, Agern Allé 11, Hørsholm 2970, Denmark \\ ${ }^{5}$ Departamento de Microbiología, Universidad Miguel Hernández, 03550 Alicante, Spain \\ Present addresses: ${ }^{6}$ Unidad de Investigación, Hospital General Universitario de Alicante, 03010 Alicante, Spain \\ ${ }^{7}$ Divisió de Microbiología, Departament de Fisiologia, Genètica i Microbiología, Universitat d'Alacant, 03080 Alacant, Spain \\ ${ }^{8}$ Institute for Limnology, Austrian Academy of Sciences, 5310 Mondsee, Austria
}

\begin{abstract}
The factors controlling prokaryote abundance and activity along salinity gradients were investigated in the Bras del Port solar saltern system (Alacant, Spain) in May 1999. Specific growth rates were high and prokaryote abundance relatively low at the lowest (seawater) salinities; the opposite was found at higher salinities. Experiments were carried out in representative salterns at salinities of 4 to $37 \%$, to test whether prokaryote abundance and growth rate were (1) limited by inorganic or organic nutrients (nutrient addition experiments), (2) limited by cell abundance (dilution experiments), or (3) affected by zooplankton cascading down to affect the prokaryote predators. Lowsalinity ponds were limited by organic nutrients, while high-salinity ponds responded slightly only to dilution. Zooplankton affected prokaryote growth rates particularly in the medium-salinity ponds. In the low salinity ponds, zooplankton effects were weak and probably indirect (through increased supply of organic matter). Neither organic matter limitation nor zooplankton predation pressure affected prokaryote development in the higher salinity ponds. We suggest that 3 types of functional communities occur in the same saltern system: (1) an active, substrate-limited community in the low salinity ponds; (2) an active, grazer-controlled community in the medium salinity ponds; and (3) a possibly dormant, probably substrate-limited, community in the high salinity ponds. However, the results at the highest salinities were equivocal, because the dilution manipulation had detrimental effects, artificially decreasing the contribution of the haloarchaea, which were essential contributors to the total activity in the saltern. Bacterial taxonomic community composition was also determined in these experiments by denaturing gradient gel electrophoresis (DGGE) analyses on 16S rRNA genes, and showed very small changes in community composition in the experimental manipulations. Together with the known microbial community structure and composition at differing salinities along the gradient, our results show that functional aspects of the microbial food web also vary between salterns.
\end{abstract}

KEY WORDS: Solar salterns • Hypersaline • Bacteria • Haloarchaea • Nutrient limitation . Heterotrophic production

\section{INTRODUCTION}

Microbes are dominant components of aquatic food webs. In some environments, such as extremely saline coastal lagoons, they may even be the only compo- nents of the food web (Pedrós-Alió 2003). Bacteria and Archaea are dominant members of the microbial food web in coastal solar salterns of the type used to obtain salt commercially (Rodríguez-Valera 1988, Pedrós-Alió et al. 2000a). However, very few studies on the 
prokaryotic ecology of hypersaline environments have been carried out, with little concern for quantification of biomass and activities of these organisms. Therefore, most functional aspects of the prokaryotic assemblage in salterns remain unknown. Knowledge of these functional aspects in this type of uncommon system has global relevance, because understanding of the mechanisms implicated in these relatively simplified systems can shed light on those determining prokaryote abundance in other, more widely distributed, environments such as the open ocean or lakes (Pedrós-Alió et al. 2000b).

The multi-pond solar salterns of Bras del Port in Santa Pola (Alacant, Spain) are an extensively studied hypersaline coastal environment. Here, seawater is pumped through a set of shallow ponds where water evaporates and salts concentrate. Finally, when seawater has been reduced to about $1 / 10$ the original volume, $\mathrm{NaCl}$ precipitates in the ponds (called crystallizers; $37 \%$ salinity) and can be collected. These salterns often operate as continuous or semi-continuous systems, so that each set of ponds maintains a similar range of salinity throughout the year. In some ponds, mainly those of higher salt content, heterotrophic prokaryotes (HPK) are very abundant but grow at very low specific growth rates. In other ponds, mainly in those of lower salt content, HPK are less concentrated and grow at high specific rates. Guixa-Boixereu et al. (1996) showed in similar salterns that protistan grazing pressure decreased with increasing salinity up to a point where it was undectable. At the highest salinities, only viruses affected prokaryotes, although the percentage of prokaryotic biomass and production lost to viruses was very small. Most likely, therefore, 2 different types of control of prokaryotic abundance are involved: in the low-salinity ponds, high grazing pressure determines a relatively low prokaryotic biomass with high specific growth rates; in the high-salinity ponds, low grazing pressure results in a relatively high prokaryote biomass with low specific growth rates. Wright (1984) postulated the existence of 3 types of bacterial assemblages: (1) the 'Active, grazer-controlled' assemblage, with moderately large assemblages, high specific activity, presence of relatively large grazer populations, and showing a large increase in bacterial numbers when predation is experimentally reduced; (2) the 'Active, substrate-limited' assemblage, with high abundance and specific activity, with low rates of growth after predators are removed; and (3) the 'Dormant, substrate-limited' assemblage, with lower abundances (compared to the maximal possible), lower cell-specific activities and no significant increases in the first hours if enriched or incubated without predators, or both. Our previous data (GuixaBoixereu et al. 1996, Pedrós-Alió et al. 2000a,b, Pedrós-
Alió 2003) suggested the salinity gradient to be equivalent to a gradient from Wright's type (1) assemblages (at low salinities) to Wright's type (3) assemblages at high salinities, with the possible existence of type (2) communities at intermediate salinities.

The 2 extreme types of interaction between grazer activity and prokaryote response that Wright defines can also be equated to what one would expect from a laboratory culture when in the middle of the exponential growth phase - relatively high abundances, high growth rate or, in the stationary phase, high abundance, low growth rate (Gasol et al. 2002b). An empirical analysis of saltern data, combined with data from other 'more common' planktonic environments (Pedrós-Alió et al. 2000b), suggested that, indeed, the amount of prokaryotic biomass in high-salinity ponds was much higher than in other environments of the same trophic level (as measured by chlorophyll a concentration), while bacterial heterotrophic production had values expected for systems with the same temperature and prokaryote abundance. Thus, we hypothesized that in these salterns HPK were at the maximum possible value given the available resources. Bacteria, therefore, did not grow more because the numbers were already close to the carrying capacity of such a resource-limited system. We, thus, expected dilution of the assemblage to stimulate the growth of the prokaryotes.

We designed several types of experiment in order to test whether HPK abundance and growth rate were (1) limited by inorganic or organic nutrients (as expected in the high-salinity salterns), (2) limited by cell abundance (as described in the paragraph above), and (3) affected by a manipulation of zooplankton cascading down to the prokaryote predators (as expected in the lowest salinity salterns). The experiments were performed in several representative solar salterns $(4 \%$ [almost seawater], 8, 11, 22 and $37 \%$ ) at Bras del Port between 17 and 28 May 1999. In this paper, we describe the bacterial and archaeal abundance and activity along the salinity gradient and the results of the 3 types of experiments reported above. A series of companion papers describe microbial diversity along the salinity gradient (Benlloch et al. 2002, Casamayor et al. 2002, Øvreås et al. 2003), primary productivity, nutrient uptake and microzooplankton grazing (Joint et al. 2002), viral assemblage structure (Sandaa et al. 2003) and the phytoplankton composition and diversity (Estrada et al. unpubl.).

\section{MATERIALS AND METHODS}

The Bras del Port solar saltern system studied is in Santa Pola, Alacant, Spain $\left(38^{\circ} 12^{\prime} \mathrm{N}, 0^{\circ} 36^{\prime} \mathrm{W}\right)$, on the 
Mediterranean coast of the Iberian Peninsula. This system is operated year-round for commercial salt production, so that each pond tends to provide a very stable environment. This saltern system has been the subject of a number of microbiological studies of extremophile bacteria and Archaea (Rodríguez-Valera 1988, Benlloch et al. 1995, Antón et al. 1999, 2000) and microbial food webs (Guixa-Boixereu et al. 1996, Pedrós-Alió et al. 2000a,b).

Sampling was carried out with a bucket fixed to the end of a pole. The corners of the ponds were avoided since organisms tend to accumulate in the downwind corners. However, in order to estimate the degree of horizontal variability, we sampled 5 different parts of a $22 \%$ salinity pond on May 25, 1999, to estimate withinpond variability. To ensure that a pond of a given salinity was representative of the majority of ponds with the same salinity, on May 25 we sampled 4 different ponds of the same salinity, located at different positions in the saltern system.

We sampled a series of ponds with increasing salinity twice (May 18 and May 26, 1999). The experiments (see below) were performed between these dates and bacterial activity in some of the ponds on May 20 (thymidine; TdR) and May 21 (leucine, Leu) was determined. Temperature was measured with a mercury thermometer and salinity with a hand refractometer.

Experimental design. We carried out 3 types of experiment: nutrient addition (NA), dilution (D) and zooplankton manipulation (ZM). In Expt NA, water was sampled from the ponds of 4,8 and $22 \%$ salinity and the following nutrient concentrations were added to replicate 21 Nalgene bottles: nothing added (Treatment CTL, for control), $25 \mu \mathrm{M}$ nitrate $+1.6 \mu \mathrm{M}$ phosphate inorganic nutrients added (Treatment I), $1 \mathrm{~g} \mathrm{l}^{-1}$ glucose $+1 \mathrm{~g} \mathrm{l}^{-1}$ acetate organic nutrients added (Treatment O), and $0.67 \mathrm{ml} \mathrm{l}^{-1}$ of Guillard's F2 solution (Guillard 1975) $+0.67 \mathrm{ml} \mathrm{l}^{-1}$ of SL12 solution (Pfennig \& Trüper 1989) micronutrients and vitamins added (Treatment V). These bottles were incubated in the laboratory at a temperature similar to the in situ temperature and sampled daily for prokaryote counts and heterotrophic activity.

The D experiments tried to mimic the effects of rainfall on the prokaryotic communities. Water was collected from the ponds at 11, 22.5 and $37 \%$ salinity and was sequentially diluted to 100 (no dilution), 85, 75 and $60 \%$ of the original salinity with $0.2 \mu \mathrm{m}$ filtered mineral freshwater. A final volume of 301 was placed in plastic transparent tanks that were incubated, uncovered, in situ. The experiments were set up on May 20 and were sampled daily for salinity (which increased throughout the incubation), temperature, heterotrophic activity and prokaryotic counts. The experiments were finished on May 27 - the $85 \%$ dilution container in the $22.5 \%$ pond had been lost due to wind on the 4 th day. Changes in bacterial community composition were followed by denaturing gradient gel electrophoresis (DGGE) of PCR-amplified 16S rRNA genes. Detailed protocols of DNA extraction and PCR-DGGE are given in another manuscript of this series (Casamayor et al. 2002).

The ZM experiments were carried out with water from the ponds at 4, 11 and $22.5 \%$ salinities to test the effects of varying macrozooplankton predation pressure on the prokaryotic communities. As reported below, the macrozooplankton community in the $4 \%$ pond was mainly composed of copepods, in the $22.5 \%$ pond it was almost exclusively composed of Artemia, and in the $11 \%$ pond the community was composed of both copepods and Artemia at rather similar levels of abundance. In each pond, 6 transparent 301 plastic containers were set up. Two served as controls, 2 had been filtered through $200 \mu \mathrm{m}$ mesh to remove large zooplankton, and the other 2 had double concentration of macrozooplankton (we added the material retained on the $200 \mu \mathrm{m}$ mesh). The tanks were incubated, uncovered, in situ. The experiments were set up on May 20 and were sampled daily for heterotrophic activity and prokaryotic counts. The experiments were finished on May 27-2 of the controls (4 and 22.5\%) had been lost on the first day due to wind. At the end of the experiment, all the water in the containers was filtered through a $200 \mu \mathrm{m}$ size mesh, and the zooplankton sampled for final counts. Visual inspection of the zooplankton samples on the last day confirmed that we were successful in removing zooplankton from some treatments while concentrating it in others, except for the $4 \%$ pond (see 'Zooplankton manipulation (Z) experiments $\left.{ }^{\prime}\right)$.

Abundance of organisms. A $1.2 \mathrm{ml}$ subsample was preserved for prokaryotic counts with $1 \%$ paraformaldehyde $+0.05 \%$ glutaraldehyde (final concentrations), frozen in liquid nitrogen and stored in a $-70^{\circ} \mathrm{C}$ freezer to determine the abundance of prokaryotes and relative size by flow cytometry. Samples were later defrosted, diluted $10 \times$ or $20 \times$ with Milli-Q water, stained for 5 min with Syto13 (Molecular Probes) at $2.5 \mu \mathrm{M}$ and run through a flow cytometer. Dilution was necessary both to avoid any problems related to salinity and staining properties of Syto13, and to reduce the number of particles so that the rate of particle passage was kept below 500 particles $\mathrm{s}^{-1}$ and, thus, coincidence was avoided (Gasol \& del Giorgio 2000). We used a Becton \& Dickinson FACScalibur machine with a laser emitting at $488 \mathrm{~nm}$. Samples were run at low speed (approx. $18 \mu \mathrm{l} \mathrm{min}{ }^{-1}$ ) and data were acquired in log mode until around 10000 events had been recorded. We added $30 \mu \mathrm{l}$ per sample of a $10^{6} \mathrm{ml}^{-1}$ solution of yellow-green $0.92 \mu \mathrm{m}$ Polysciences latex beads as an 
internal standard. Bacteria were detected by their signature in a plot of side scatter (SSC) versus green fluorescence (FL1) as explained in Gasol \& del Giorgio (2000). High nucleic acid bacteria (HNA) and low nucleic acid bacteria (LNA) were determined as explained in the above reference. The average fluorescence of the bacterial population, as normalized to that of the beads, is a rough approximation of bacterial size, although in such a eutrophic environment (with most bacteria being large, filamentous and even square shaped; Guixa-Boixereu et al. 1996, Antón et al. 1999), average fluorescence is most probably an underestimation of size. Bacterial size was converted to weight using the carbon-to-volume relationship derived by Norland (1993).

During the second survey (May 26), we sampled between 20 and 401 for zooplankton biomass estimations. The samples were concentrated on a $40 \mu \mathrm{m}$ Nytex mesh and later transferred to a bottle with $4 \%$ final concentration of formalin. We counted aliquots of the concentrated sample until we accounted for 30 to $100 \%$ of the total sample volume. All individuals were sized, a general length-to-dry weight regression (McCauley 1984) was applied to obtain dry weights, and all weights were pooled. Dry weight was transformed to carbon biomass with a constant $40 \%$ value.

Microbial activities. Microbial heterotrophic activity was measured both as ${ }^{3} \mathrm{H}$-Leu incorporation assays in all samplings following Kirchman (1993) with slight modifications, and with ${ }^{3} \mathrm{H}-\mathrm{TdR}$ incorporation following Bell (1993). In the radioactivity incubations, $1.5 \mathrm{ml}$ samples were incubated with 20 to $40 \mathrm{nM}$ Leu 1 : 9 hot:cold v/v, around $150 \mathrm{Ci} \mathrm{mmol}^{-1}$ ) in Eppendorf vials, as in Smith \& Azam (1992). This concentration was shown to be saturating in experiments carried out in the May 1993 visit to a similar saltern in La Trinitat (Pedrós-Alió et al. 2000a). Four replicates plus 2 TCAkilled controls (5\% final concentration) were incubated for each pond. In the May 21 survey, $1.7 \mathrm{ml}$ samples were used, incubated with $20 \mathrm{nM}$ Leu, and the controls were killed with $2.5 \%$ glutaraldehyde. Incubations were carried out in the dark at ambient temperature for $\sim 45$ to $60 \mathrm{~min}$. Time-course experiments showed that incorporation was linear for longer than the standard incubation period of $1 \mathrm{~h}$. Data of Leu incorporation was converted to estimates of prokaryotic production by using the conversion factor $3.1 \mathrm{~kg} \mathrm{C}$ $\mathrm{mol}^{-1}$ Leu incorporated that assumes a 2-fold dilution of the added Leu with the ambient Leu (Simon \& Azam 1989). Specific growth rates $(\mu)$ and doubling times $\left(D_{t}\right)$ were calculated from these production estimates and those of total prokaryotic biomass. We determined empirical conversion factors in 2 ponds (11 and 37\% salinity), and the prokaryotic growth rates obtained using these values are quite similar to those calculated using the theoretical value (see also Fig. 5 in PedrósAlió et al. 2000a). Given that to apply an empirically derived factor for one pond to data from another pond may also introduce errors, we choose to present the growth rates calculated with the standard conversion factor. TdR incorporation was determined in $0.9 \mathrm{ml}$ subsamples in Eppendorf tubes. Controls were done with $50 \mu \mathrm{l} 100 \%$ TCA, TdR added at a final concentration of $40 \mathrm{nM}$, and samples incubated for $1 \mathrm{~h}$ at $30^{\circ} \mathrm{C}$.

We also used the technique introduced by Oren $(1990 a, b)$ as a way to determine the activity of bacteria and haloarchaea separately. The technique uses bile salts to lyse halophylic archaea (Kamekura et al. 1988). Thus, activity in samples treated with bile salt corresponds to bacteria, while the activity in untreated samples corresponds to bacteria plus haloarchaea, at least in the high salinity ponds. However, this technique is not absolutely foolproof since Halococcus and some Halobacterium species are not lysed by sodium taurocholate (Tchl) (the detergent commonly used), although Halococcus is believed to play a small role in natural systems (Rodríguez-Valera 1988, Oren 1990a, Casamayor et al. 2000, Benlloch et al. 2002). Na-Tchl (at a final concentration of $50 \mu \mathrm{g} \mathrm{ml}^{-1}$ ) was used to lyse the archaea and thus prevent incorporation by these organisms, and was added before the start of incubations. In the past, and in the same salterns, we had double-checked the method by carrying out parallel incubations with an inhibitor of bacteria (erythromycin; Pedrós-Alió et al. 2000a) with quite satisfactory results.

We also evaluated the response of microbial communities to the addition of a variety of carbon sources, as a way of functionally differentiating between assemblages (e.g. Garland \& Mills 1991, Worm et al. 2001). The prokaryotic response was measured as a change in TdR uptake rate after $20 \mathrm{~h}$ incubation of $0.8 \mathrm{ml}$ samples placed in acid-clean Eppendorf tubes to which $0.1 \mathrm{ml}$ of 18 different carbon substrates had been added. The carbon solutions also contained $\mathrm{N}$ and $\mathrm{P}$ in order to avoid nutrient depletion and, thus, final additions consisted in $1 \mathrm{mg} \mathrm{ml}^{-1}$ carbon and $100 \mu \mathrm{M}$ nitrogen and $8 \mu \mathrm{M}$ P. Carbon solutions were added to the water samples at the beginning of the experiment and were kept in the dark at $30^{\circ} \mathrm{C}$ for the following $20 \mathrm{~h}$. After incubation, TdR was added and the samples were incubated for $1 \mathrm{~h}$ under the same conditions. Besides the ammendments with the 18 carbon compounds (see Table 2), one set of water samples received only inorganic nutrients, another received distilled water and a third received no additions. For each set, there were 2 replicates and 1 killed control. The first 17 substrates (see Table 2) are also found in BIOLOG wells. Glycerol was also included in this study, because of its importance as a storage product in Dunaliella (Oren 1999). 


\section{RESULTS AND DISCUSSION}

\section{Variability in abundance of prokaryotes between and within ponds}

A solar saltern system usually has several different ponds with the same salinity. Water can be in a pond for a variable length of time, and potential for amongpond variability exists. We wanted to check whether choosing one pond was representative of the values in other ponds with the same salinity. We found that different ponds of the same salinity had very similar total abundance of prokaryotes (Table 1), with coefficients of variation between 3 and $4.4 \%$. Similarly, we expected horizontal variability to exist within shallow ponds with large surfaces exposed to the action of the wind. However, a single check in one pond showed the different sides of the pond to have quite similar abundance of prokaryotes (CV of $10 \%$, Table 1). These results imply that our sampling and experiments performed in just 1 pond per salinity value can be extrapolated to other ponds, at least within the same saltern system. Previous biogeochemical (Pedrós-Alió et al. 2000a) and molecular diversity work (Casamayor et al. 2000) also suggested that even in different solar saltern systems, ponds of the same salinity behave similarly. This is in contrast to the distribution of larger organisms. Joint et al. (2002), for example, found substantial heterogeneity in the distribution of Dunaliella among

Table 1. Variability in the concentration of prokaryotes in different ponds: total abundance of heterotrophic prokaryotes (HPK), relative contribution of high nucleic acid-containing bacteria (\%HNA) and coefficient of variation for the replicate ponds

\begin{tabular}{|lrrrrc|}
\hline Salinity (\%) & Sample \# & \%HNA & $\begin{array}{c}\text { HPK } \\
\times 10^{7} \mathrm{ml}^{-1}\end{array}$ & $\begin{array}{c}\text { CV HNA } \\
\%\end{array}$ & $\begin{array}{c}\text { CV HPK } \\
\%\end{array}$ \\
\hline Between ponds & & & & & \\
22 & 1 & 86.9 & 1.40 & 0.4 & 3.1 \\
22 & 2 & 87.4 & 1.56 & & \\
22 & 3 & 87.1 & 1.61 & & \\
22 & 4 & 88.4 & 1.59 & & \\
30 & 1 & 86.9 & 1.04 & 0.9 & \\
30 & 2 & 85.8 & 1.22 & & \\
30 & 3 & 89.4 & 1.25 & & \\
30 & 4 & 88.3 & 1.17 & & \\
37 & 1 & 85.1 & 0.81 & 2.1 & \\
37 & 2 & 90.2 & 0.95 & & \\
37 & 3 & 84.9 & 0.87 & & \\
37 & 4 & 81.3 & 0.99 & & \\
Within the same pond & & & & \\
22 & $\mathrm{~A}$ & 89.5 & 1.17 & 1.5 & \\
22 & $\mathrm{~B}$ & 82.7 & 1.27 & & \\
22 & $\mathrm{C}$ & 85.6 & 1.76 & & \\
22 & $\mathrm{D}$ & 86.2 & 0.97 & & \\
22 & $\mathrm{E}$ & 82.4 & 1.45 & & \\
\hline
\end{tabular}

and within ponds, and the variability is even more marked for Artemia distributions (Haslett \& Wear 1985).

\section{Abundance of organisms along the salinity gradient}

Chlorophyll a concentrations (Joint et al. 2002) and cyanobacteria, pico- and nanoalgal abundances and diversity (Estrada et al. unpubl.) have been described in other manuscripts. HPKwere very abundant in the ponds, with concentrations ranging from 3 to $16 \times 10^{6}$ cells $\mathrm{ml}^{-1}$ (Fig. 1). Substantial variation was detected between May 18 and May 26 in both surveys, especially in the $11 \%$ salinity pond. Most of the prokaryotes had a HNA content (from 80 to $95 \%$ of the prokaryotes were HNA, Fig. 1), which would imply that most of them were active given the evidence presented by Gasol et al. (1999) and Lebaron et al. (2001) regarding the significance of the nucleic acid content in bacteria as detected by flow cytometry of nucleic acid-stained samples. However, this does not necessarily mean that bacteria were actively growing but, rather, that they had an active physiological status (i.e. a cell with active synthesis of osmolites or other substances to keep functionality under extreme conditions, could also be detected as a HNA cell). Nucleic acid cellular content (as measured by the green fluorescence of the cells after staining with Syto13) increased from the lower to the higher salinity ponds (Fig. 1), and cell size most probably also did so, given the general correlation between cell size and Syto13 fluorescence (i.e. Gasol \& del Giorgio 2000). The abundances detected were lower than those encountered in the same system in July 1993 (maximum of $1.6 \times 10^{8}$ cells $\mathrm{ml}^{-1}$; Pedrós-Alió et al. 2000a). The difference in abundance of prokaryotes could be related to the more advanced season of the 1993 sampling. Studies following the microbial community through a seasonal cycle in salterns have not been done and there is no background information available to extract further conclusions (i.e. PedrósAlió 2003), although a similar difference was found between spring and summer samples in la Trinitat, another saltern system in northeast Spain (Pedrós-Alió et al. 2000a).

Macrozooplankton assemblages showed the highest biomass at salinities from 15 to $25 \%$, at which Artemia completely dominated the community, 

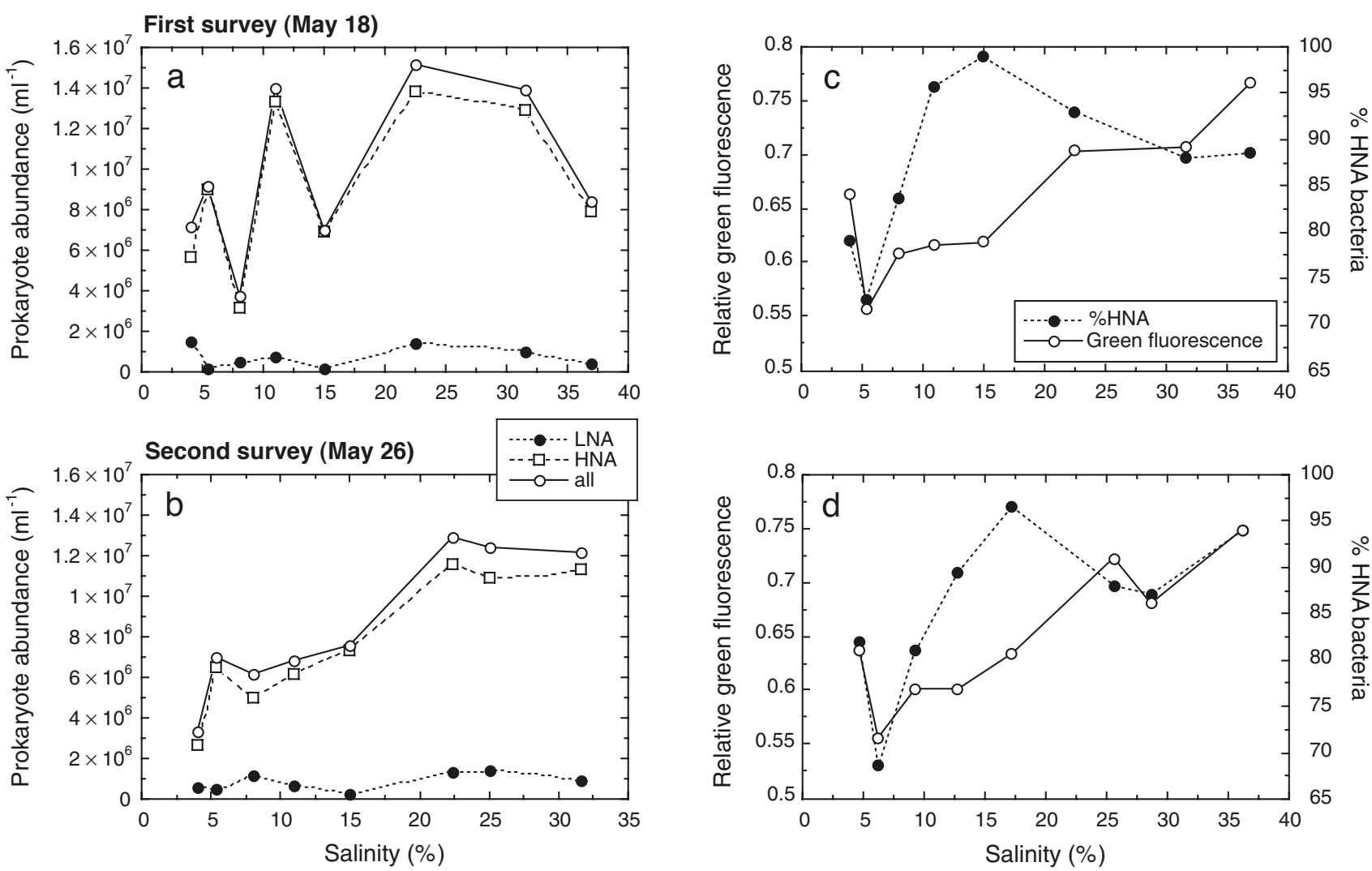

Fig. 1. Abundance of prokaryotes and some average cellular characteristics. (a,b) LNA (low nucleic acid containing) prokaryote abundance; HNA (high nucleic acid containing) prokaryote abundance; and total prokaryotic abundance. (c,d) Relative green fluorescence, standardized to $1 \mu \mathrm{m}$ Polysciences beads; and \% of HNA containing prokaryotes in different ponds of varying salinity during the surveys on May $18(\mathrm{a}, \mathrm{c})$ and May $26(\mathrm{~b}, \mathrm{~d})$

reaching $10 \mathrm{mgC}^{-1}$ (Fig. 2). At salinities below $8 \%$, only copepods and a few ostracods were present, and in the $11 \%$ salinity pond both copepods and Artemia shared the biomass. No macrozooplankton was present in the higher salinity ponds.

\section{Prokaryotic heterotrophic production and growth rates along the salinity gradient}

Prokaryotic heterotrophic activity, and therefore prokaryotic heterotrophic production, was much higher in the low salinity ponds than in the higher salinity ponds (Figs. $3 \& 4$ ). A 5 -fold variation could be measured from end to end of the salinity gradient, with 1 exception ( $8 \%$ pond): the percent of total activity that was resistant to Tchl was $\sim 80 \%$ in the lower salinity ponds, but decreased to almost 0 at salinities above $30 \%$. Assuming that Tchl and other bile salts inhibit the activity of haloarchaea (Kamekura et al. 1988, Oren $1990 \mathrm{a}, \mathrm{b})$, most of the prokaryotic activity above $25 \%$ (and especially above $32 \%$ salinity) was carried out by haloarchaea. Therefore, the halophylic bac- terium Salinibacter, originally isolated from the Santa Pola salterns, would have contributed insignificantly to the in situ Leu incorporation in the highest salinity

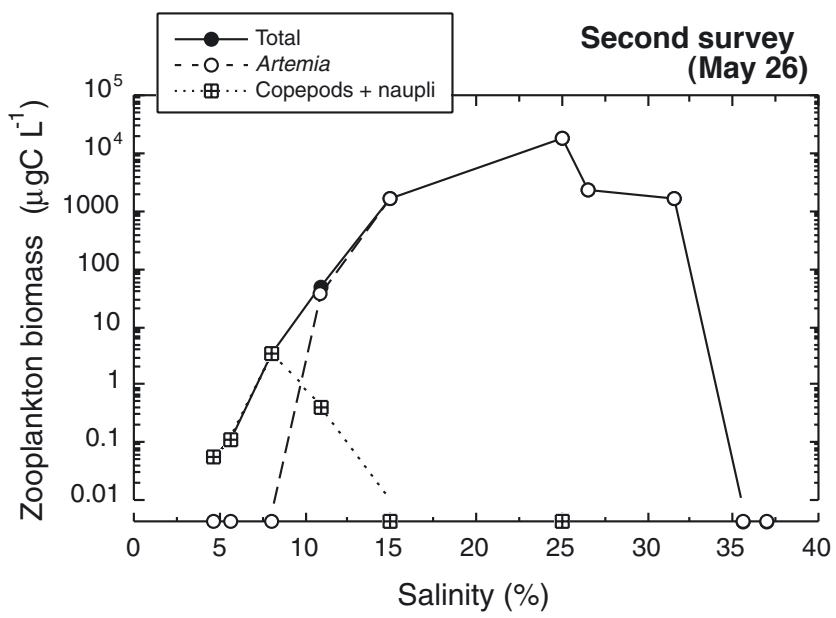

Fig. 2. Total macrozooplankton biomass, and the contribution of Artemia and copepods, in the different ponds during the second survey (May 26). Note that the vertical scale is logarithmic 

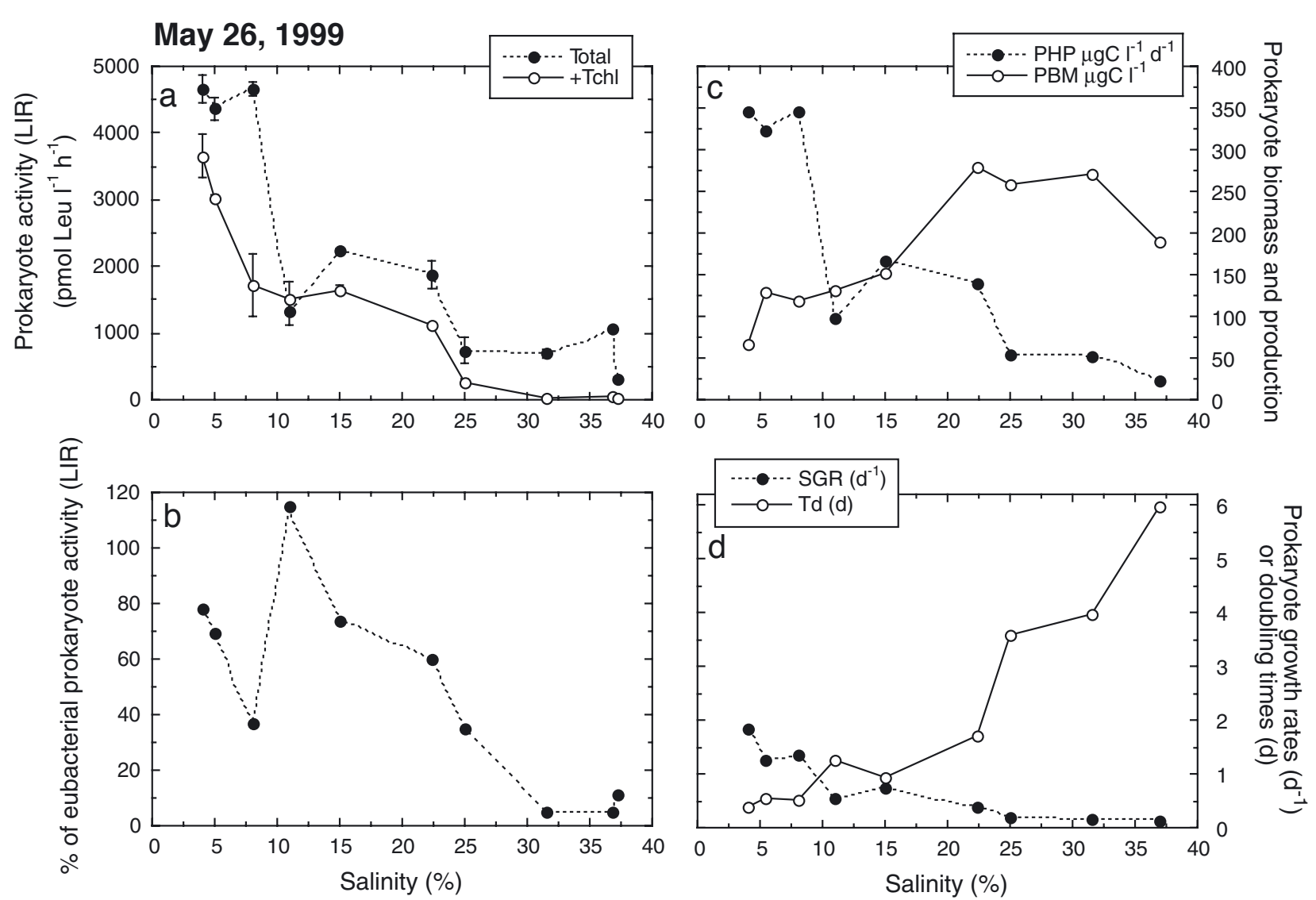

Fig. 3. Prokaryotic heterotrophic activity and growth rates in ponds of varying salinity during the May 26 survey. (a) Total leucine incorporation rates (LIR) and LIR in the presence of the haloarchaeal inhibitor taurocholate (+Tchl). (b) Percentage of total heterotrophic activity in the presence of Tchl; (c) Estimated total prokaryotic biomass (PBM) and production (PHP). (d) Total prokaryotic growth rates and doubling times; SGR: specific growth rate; Td: duplication time

ponds despite the fact that they reached up to $18 \%$ of total DAPI counts in the crystallizers (Antón et al. 2000). An alternative explanation could be that this

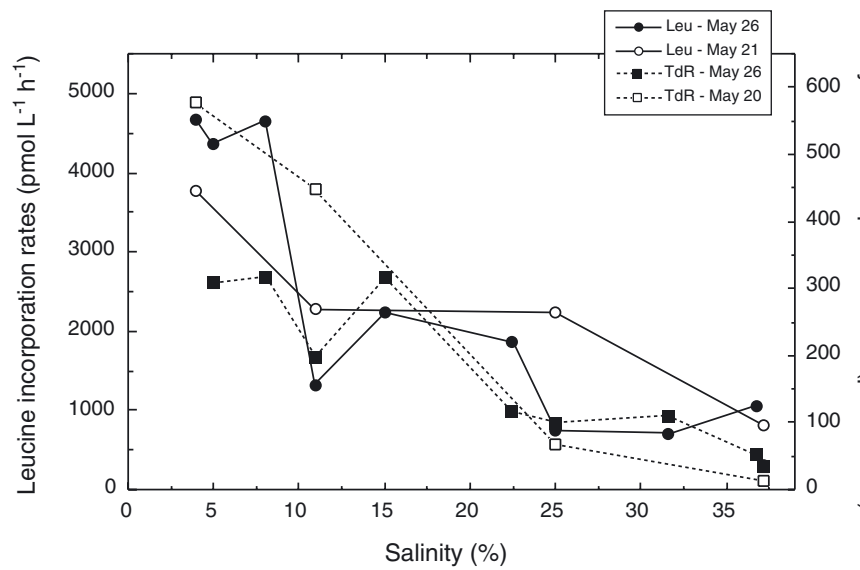

Fig. 4. Comparison of bacterial activity in different ponds of varying salinity using different techniques, leucine and thymidine incorporation, and at different dates during May 1999. Note that the scale for leucine incorporation is on the left, while the scale for the thymidine incorporation is on the right organism is sensitive to Tchl. Polar lipid analysis from Santa Pola also showed the total contribution of Bacteria to be minor compared to that of the halophilic Archaea (Oren \& Rodríguez-Valera 2001). Our results for Tchl were very similar to those of Oren (1990a) and Pedrós-Alió et al. (2000a) in Eilat, and La Trinitat and Santa Pola salterns, respectively.

Comparing cell numbers (Fig. 1) and activity measurements (Fig. 3), prokaryotes grew fast in the low salinity ponds (doubling time $<1 \mathrm{~d}$ ), and more slowly in the highest salinity ponds (doubling time $>5 \mathrm{~d}$ in the $37 \%$ pond). Thus, a relatively diluted community was growing fast at one end, and a very concentrated community was growing at a very low rate at the other end of the gradient. This is in agreement with previous surveys carried out in similar salterns (Pedrós-Alió et al. 2000a, Pedrós-Alió 2003). Bacterial activity was also determined 3 times with both Leu and TdR incorporation methods around the time of the second survey (May 20 to 26). Both rates of uptake changed in a similar way with salinity (Fig. 4) and the 2 rates were significantly positively correlated (for all data, Pearson's $\mathrm{R}=0.73, \mathrm{~N}=13, \mathrm{p}=0.049$; and for the samples taken 
simultaneously, Pearson's $\mathrm{R}=0.85, \mathrm{~N}=9, \mathrm{p}=0.028$ ). The Leu:TdR ratio, often assumed to indicate whether prokaryotic growth is balanced or not, ranged between 4 and 20 (average $=11$ ), which would indicate a rather balanced growth in all ponds. This ratio commonly varies between 5 and 40 (Chin-Leo \& Kirchman 1990). From Fig. 4 it is possible to derive a tendency for higher values of the Leu:TdR ratio in the low salinity ponds, and lower values in the higher salinity ponds, at least for May 26, when both TdR and Leu incorporation were measured simultaneously. Given that we found a relatively similar trend in Leu and TdR incorporation along the salinity gradient (Fig. 4), we consider that our values of Leu incorporation are reasonable estimates of bacterial activity, at least comparable between ponds.

Bacteria in the higher salinity ponds were growing at a very slow rate (Fig. 3), but they seemed to be doing so in a rather balanced way (according to the Leu:TdR ratios), and this would indicate nutrient and energy sufficiency for bacterial growth at these salinities. Within this framework, experimental manipulations were carried out and the changes induced in prokaryotic abundance and activity were determined in order to elucidate the controls operating on heterotrophic prokaryotic growth rate and abundance in hypersaline environments. As explained in the 'Introduction', the information we had collected previously (GuixaBoixereu et al. 1996) suggested the existence of a Wright's (1984) type (1) community at low salinities and a Wright's type (3) community at high salinities, with the possible existence of type (2) communities at intermediate salinities. We also expected dilution (and/or addition of nutrients) to stimulate prokaryote growth in the high salinity communities.

\section{Changes induced in nutrient addition (NA) experiments}

The increase in prokaryotic abundance and in total Leu incorporation rates (LIR) was determined in water from 4 ponds after addition of inorganic nutrients (Treatment I), organic matter (Treatment O), micronutrients and vitamins (Treatment $\mathrm{V}$ ) or no additions (Treatment CTL). Initial nutrient concentrations were around 2 to $5 \mu \mathrm{M}$ nitrate and a similar ammonia concentration (Joint et al. 2002); thus the added inorganic nutrient concentrations were approximately $10 \times$ the in situ concentrations. In our experiment (Fig. 5), it was obvious that Treatment I did not significantly increase either the activity or the abundance of prokaryotes in any of the ponds, with the exception of a slight increase in abundance for the $37 \%$ salinity pond. Conversely, Treatment $\mathrm{O}$ (addition of glucose and acetate) stimulated LIR in all ponds, except at $37 \%$ salinity (crystallizer). This resulted in stimulation of the prokaryotic growth rate, especially for the $4 \%$ salinity pond. Treatment $V$ had no effects except in the crystallizer, where unexpectedly LIR consistently decreased. These data indicate that in the low salinity ponds HPK were mostly limited by organic matter, and that this limitation decreased as salinity increased. Neither inorganic compounds nor micronutrients or vitamins were limiting factors. In a simultaneous study, Joint et al. (2002) found that neither phosphorus nor ammonia increased carbon fixation in the salterns, using the same concentrations as we did.

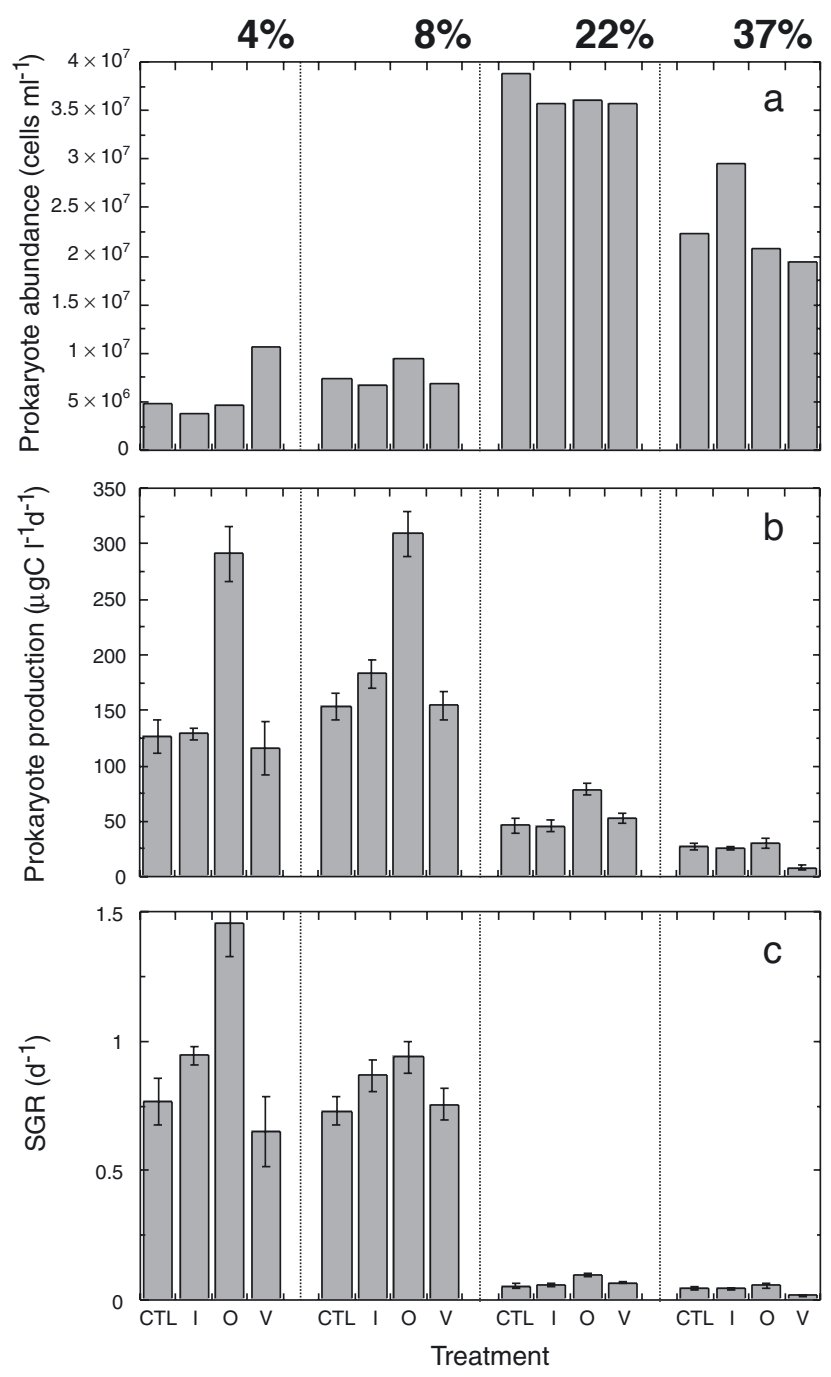

Fig. 5. Summary of the results of the nutrient addition experiments. For each of the ponds studied $(4,8,22$ and $37 \%$ salinity), the results are presented for (a) prokaryotic abundance after $4 \mathrm{~d}$ of incubation, (b) prokaryote production averaged for the $4 \mathrm{~d}$ of incubation, and (c) prokaryotic specific growth rates (SGR) (calculated for the 4th day). Treatments are: CTL, control (no additions); I, addition of inorganic nutrients; O, addition of organic nutrients; and $\mathrm{V}$, addition of a micronutrient and vitamin solution (see text for details) 
Further evidence for the pattern observed in the experiment can be obtained from the carbon-addition experiments in which the response of the prokaryotic assemblage to the addition of inorganic and organic nutrients was studied by TdR incorporation (Table 2). In this experiment, inorganic nutrients did not significantly increase TdR uptake in any of the ponds above $10 \%$, and only slightly in the ponds at lower salinities, in agreement with the results reported above. For the $4 \%$ pond, most of the different organic compounds tested significantly increased TdR incorporation; for higher salinities, however, almost no compounds substantially increased TdR incorporation. These results also indicate organic matter limitation to decrease with increasing salinity. In addition, we detected a lower range of compounds producing positive responses as salinity increased (Table 2). This could be explained by the decrease in microbial species richness along the increasing salinity gradient (Benlloch et al. 2002) and would suggest that the less diverse microbial assemblages would have lower ability for degrading some of the compounds added in the experiment. A few compounds (such as pyruvate and phenylethylamine) con-

Table 2. Relative stimulation or inhibition of total prokaryotic activity as measured with the incorporation of radiolabelled thymidine, in samples of 4 different salterns to which the different organic compounds were added (expressed as \% of the control sample). We also present the control with no organic compounds, but only inorganic nutrients, as inorganic nutrients were added in all cases

\begin{tabular}{|c|c|c|c|c|}
\hline \multirow{2}{*}{ Compound } & \multicolumn{4}{|c|}{ Salinity } \\
\hline & $4 \%$ & $8 \%$ & $11 \%$ & $37 \%$ \\
\hline \multicolumn{5}{|l|}{ Amino acids } \\
\hline L-phenylalanine & 140 & 88 & 79 & 138 \\
\hline L-asparagine & 260 & 116 & 100 & 117 \\
\hline L-arginine & 317 & 111 & 78 & 85 \\
\hline L-threonine & 46 & 23 & 16 & 137 \\
\hline \multicolumn{5}{|l|}{ Carbohydrates } \\
\hline Meso-Erythritol & 126 & 130 & 97 & 118 \\
\hline D-manitol & 286 & 178 & 152 & 129 \\
\hline D-xylose & 486 & 139 & 123 & 98 \\
\hline \multicolumn{5}{|l|}{ Carboxyl acids } \\
\hline Hydroxybenzoic acid & 297 & 124 & 107 & 77 \\
\hline D-galacturonic acid & 502 & 117 & 94 & 90 \\
\hline D-glucosamine hydrochloride & 129 & 67 & 64 & 118 \\
\hline 4-hydroxybenzoic acid & 357 & 121 & 95 & 87 \\
\hline \multicolumn{5}{|l|}{ Polymers } \\
\hline$\alpha$-cyclodextrin hydrate & 469 & 117 & 106 & 89 \\
\hline D-glycogen & 343 & 114 & 91 & 81 \\
\hline Tween 40 & 138 & 20 & 93 & 51 \\
\hline Tween 80 & 177 & 83 & 74 & 66 \\
\hline \multicolumn{5}{|l|}{ Other } \\
\hline Pyruvic acid & 0 & 0 & 0 & 13 \\
\hline 2-phenylethylamine & 3 & 2 & 0 & 77 \\
\hline Glycerol & 291 & 113 & 142 & 52 \\
\hline Inorganic nutrients & 144 & 110 & 93 & 88 \\
\hline Control & 100 & 100 & 100 & 100 \\
\hline
\end{tabular}

sistently decreased prokaryotic activity in all ponds. In some other cases, such as the amino acid threonine, inhibition was stronger in the low salinity ponds (4 to $11 \%$ salinity, where Bacteria were predominant components of the prokaryotic assemblages) than in the ponds with the highest salinity (where Archaea were more abundant; Antón et al. 2000, Casamayor et al. 2002). Threonine is known to affect the biosynthesis of $\mathrm{S}$-adenosylmethionine (SAM) in several species of bacteria, and reduced intracellular levels of SAM are correlated with defective chemotactic movements and reduced developmental gene expression (Shi \& Zusman 1995, and references therein).

These results somehow contradicted our initial hypotheses, in that the high salinity communities seemed not to be limited by resources, and the lower salinity communities (limited by organic nutrients) seemed to be closer to Wright's type (2) communities ('Active, substrate-limited') instead of to Wright's type (1), which would correspond more to the assemblages at middle salinities ('Active, grazer-controlled').

\section{Changes induced in the dilution (D) experiments}

These experiments tried to mimic the effect of rainfall on the prokaryotic communities, and focused on the most concentrated but slowly growing populations, such as those from the most saline ponds. There are published reports of immediate responses of microbial communities in shallow saline pools to rainfall (Kirschner et al. 2002), and we thus expected strong changes to occur within a week's time. Three ponds were tested: 11, 22 and $37 \%$ salinity. A salinity increase of around $0.5 \% \mathrm{~d}^{-1}$ occurred during the incubations. After $7 \mathrm{~d}$ of incubation, prokaryotic abundance had not recovered initial values in any of the dilution treatments (Fig. 6, where 100 is the control with no dilution) except in the $85 \%$ dilution for the $22 \%$ salinity pond, where maximal prokaryotic activities were also measured. Final prokaryotic abundance in the diluted experiments was lower than in the no-dilution treatments. In contrast cell abundances in the $37 \%$ salinity pond were much lower (more than 50\% reduction) than in the no-dilution treatment; in the $11 \%$ pond final prokaryotic abundances were smaller and smaller in parallel 

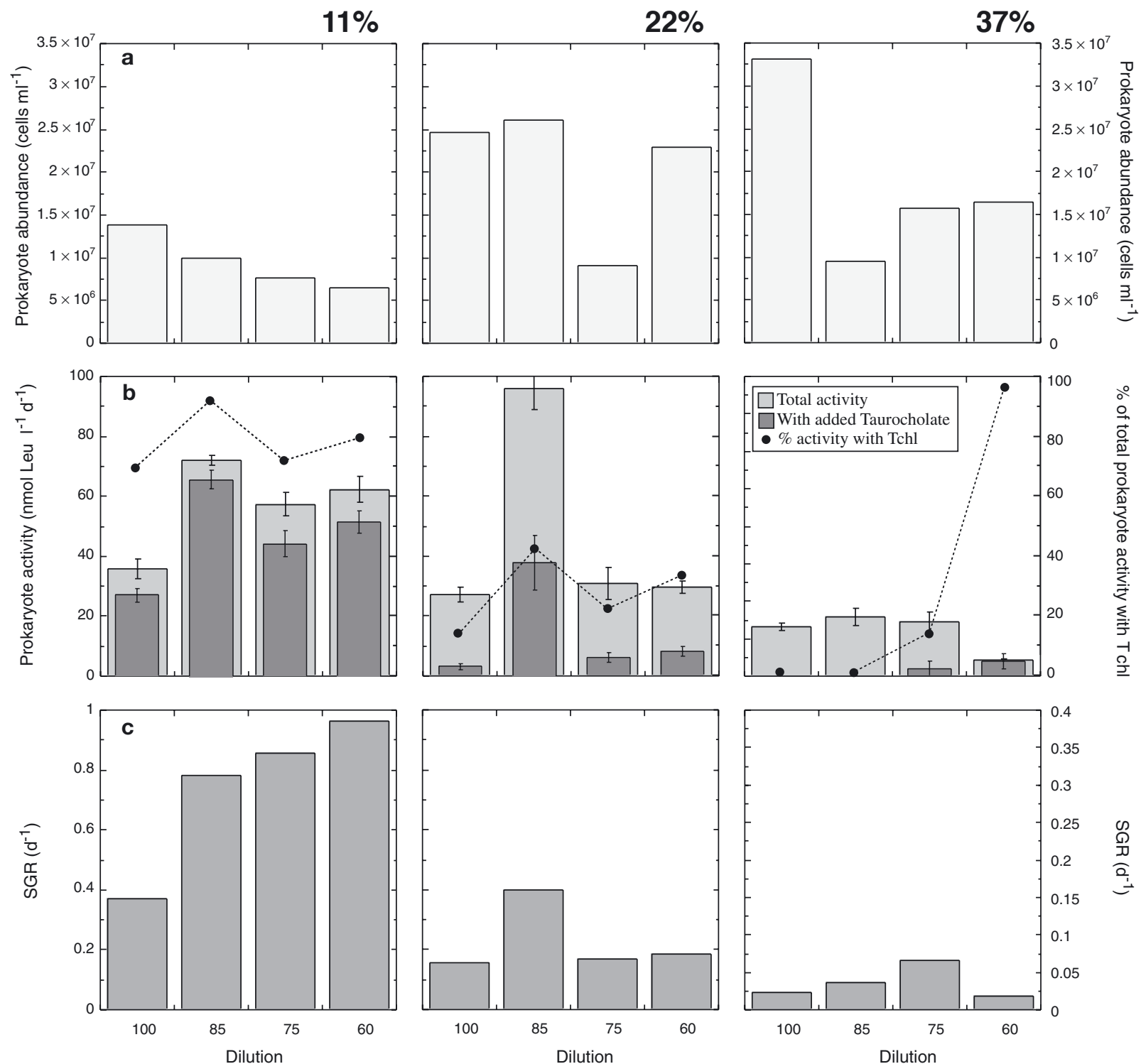

Fig. 6. Summary of the results of the dilution experiments. For each of the ponds studied (11, 22 and $37 \%$ salinity), the results are presented for (a) prokaryotic abundance averaged throughout the incubation, (b) prokaryote activity averaged for the total incubation, and (c) prokaryotic specific growth rates (SGR) (averaged throughout the incubation). (b) Note that the scale for total activity recorded with added taurocholate (Tchl) is to the right of the panels. Treatments were: 100, control (no dilution); 85, dilution at 85:15 sample:water; 75, dilution at 75:25 sample:water; and 60, dilution at 60:40 sample:water

with dilution. On the other hand, growth rate and production were stimulated by dilution in the $11 \%$ salinity pond and in the less-diluted treatment in the $22 \%$ pond, but not in the remaining treatments. Kirschner et al. (2002) observed a similar trend in a series of shallow saline pools (up to $4.5 \%$ total salt concentration) following a heavy rainfall period. A significant and immediate enhancement of bacterial growth was measured after rainfall. Growth rates were strongly stimulated by dilution in the $11 \%$ salinity saltern, and slightly stimulated by the lower dilution in both the 22 and the $37 \%$ salterns.
Samples were incubated in open boxes placed within the salterns, and were subjected to evaporation with no replacement of water; thus, salinities increased during the $7 \mathrm{~d}$ period. We think these data suggest that the activity of certain bacterial groups might have been inhibited by salinity changes. Further, dilution in the highest salinity ponds, and at the highest dilution values, probably lead to cell lysis by osmotic shock. DGGE fingerprints of bacterial DNA, however, did not show significant changes in the composition of the bacterial assemblages (Fig. 7), except in the $22 \%$ salinity pond, where we observed a reduction in the number of 
bands from the initial community to that after incubation in all treatments. Changes in the activity level of given populations would have been better reflected by detecting changes in the RNA content (by RT-PCRDGGE, e.g. Casamayor et al. 2001). Nevertheless, changes were not strong enough to generate a change in bacterial community structure as detected by PCR of 16S rDNA. Therefore, bacterial assemblages from the salterns seemed to be rather stable communities when subjected to environmental perturbations.

In all cases, dilution increased the activity of the prokaryotes but not that of the haloarchaea (Tchltreated samples). Among other possible explanations, this may indicate that bacteria could better tolerate the osmotic shock, or that some bacterial species were not at their optimal salinity for growth in situ. For example, the addition of Tchl in the $37 \%$ pond totally inhibited Leu uptake in the non-diluted treatment. This is in agreement with LIR being exclusively carried out by Archaea in the crystallizers. However, as dilution increased ( $75 \%$ and, especially, $60 \%$ dilution) the contribution of bacteria (i.e. the halophilic bacterium Salinibacter) increased, until it reached nearly $100 \%$ of the total LIR (Fig. 6, bottom right-hand panel). In laboratory experiments, it has been observed that higher Salinibacter growth yields could be obtained at salinities of 20 to $25 \%$ than at 30 to $37 \%$ (the salinity from which this bacterium had been originally isolated; Antón et al. 2000), a pattern that would agree with the results obtained in our manipulations.
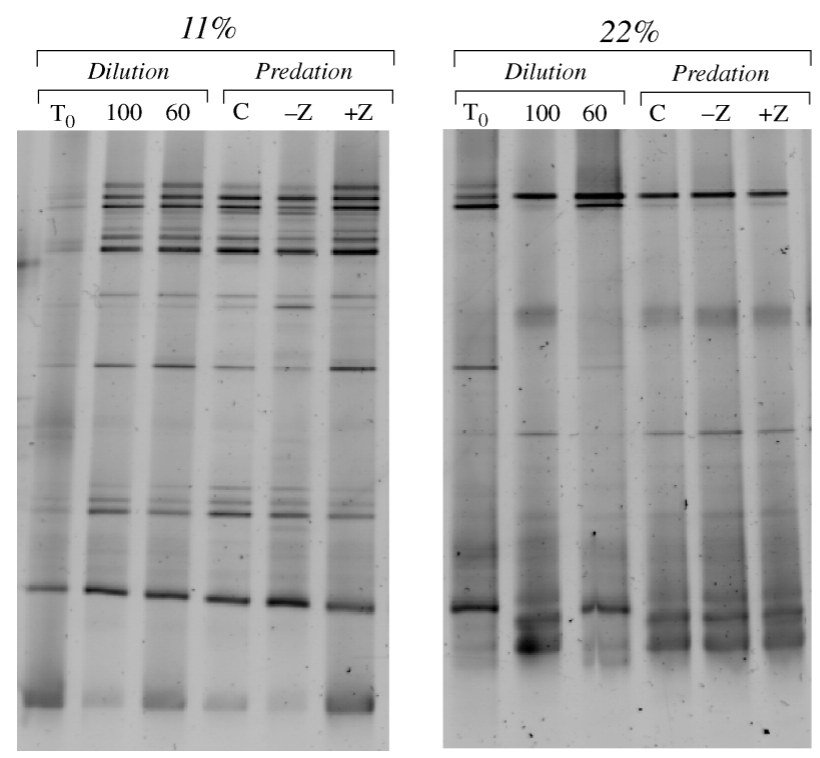

Fig. 7. DGGE fingerprints of bacterial diversity in the dilution and zooplankton manipulation experiments in ponds of 11,22 or $37 \%$ salinity as obtained after PCR-amplification with Bacteria primers. For the dilution experiments, only the initial $\left(\mathrm{T}_{0}\right)$ and final results at no dilution (100) or $60 \%$ dilution (60) are presented. C: control (no modification of the present zooplankton); $-\mathrm{Z}$ : zooplankton absent; $+\mathrm{Z}$ : double the zooplankton concentration

\section{Zooplankton manipulation (Z) experiments}

These experiments intended to mimic the effect of a cut-off of the trophic interactions by eliminating, or concentrating, the mesozooplankton $(>200 \mu \mathrm{m})$ and were performed in the 4,11 , and $22 \%$ salinity ponds (Fig. 8). In fact, we were successful in manipulating the zooplankton community of the $11 \%$ salinity (where Artemia and copepods both participated in total macrozooplankton biomass, Fig. 2) since final biomass in the $+Z$ treatment was 1.98 times the control biomass (i.e. initial biomass), and the biomass in the $-Z$ treatment was $13 \%$ of the initial biomass. Similarly, in the $22 \%$ salinity pond, where all zooplankton biomass was composed of Artemia, the $+\mathrm{Z}$ treatment at the end of the experiment had 2.02 times the control biomass, while no zooplankton were detected in the $-\mathrm{Z}$ treatment. In the $4 \%$ salinity pond, however, we were not successful in creating truly $-\mathrm{Z}$ treatments, probably due to the large mesh size used in a community dominated by copepods and nauplii.

We had previous information that protist bacterivory was relatively low at the lowest salinity $(4 \%)$, very high at intermediate salinities and zero at salinities higher than $22 \%$, at least in the La Trinitat salterns, a few hundred km north of Santa Pola (Guixa-Boixereu et al. 1996). We thus expected little effect of zooplankton manipulations on bacterial growth in the higher salinity ponds, unless Artemia were to feed directly on bacteria, an unlikely possibility. In the lower salinity

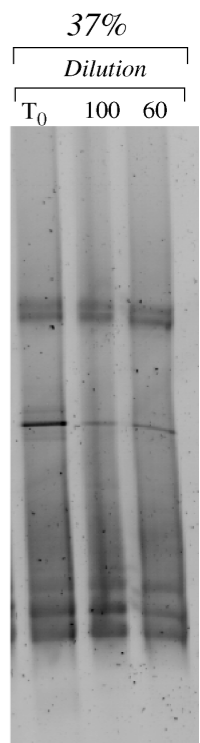
ponds of La Trinitat, bacterial losses to protistan predators explained less than $50 \%$ of bacterial production (Guixa-Boixereu et al. 1996) and, thus, we would expect the zooplankton manipulation not to directly effect bacteria except for the increased substrate supply that the manipulations could provide. Finally, in the medium salinity $(19 \%)$ ponds of La Trinitat, bacterial losses to grazing were sometimes higher than $100 \%$ of bacterial production, suggesting that a tight bacterial-protist relationship was present. If that were also the case in the Santa Pola salterns, we would expect in our experiments that the reduction of zooplankton pressure on protists would generate a higher impact on bacteria and, thus, reduced bacterial abundances and higher growth rates. In parallel to this, the increase in zooplankton abundance would decrease protist abundance, and allow an increase in bacterial 


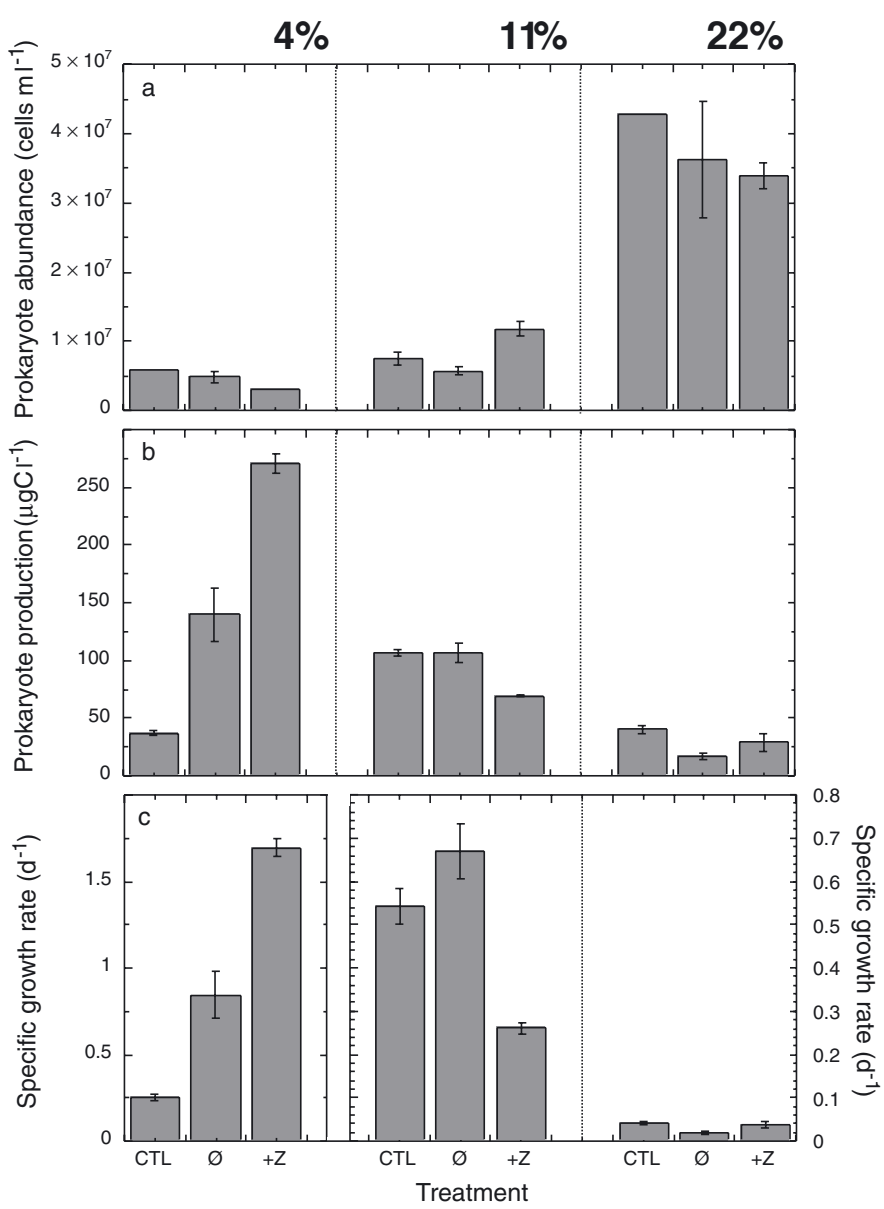

Fig. 8. Summary of the results of the zooplankton manipulation experiments. For each of the ponds studied $(4,11$ and $22 \%$ salinity), the results are presented for (a) prokaryotic abundance averaged for the whole incubation, (b) prokaryote production averaged for the total incubation, and (c) prokaryotic specific growth rates (averaged for the total days of incubation). Treatments were: CTL, control (no manipulation); $\varnothing$, removal of zooplankton $>200 \mu \mathrm{m}$; and Z, addition of the zooplankton $>200 \mu \mathrm{m}$ removed from the $\varnothing$ treatment. Note that there are 2 different scales for specific growth rates

abundance and a decrease in specific rates of growth.

As expected, the zooplankton manipulation treatments affected only the 2 ponds with the lowest salinities, whereas changes in the $22 \%$ salinity treatments were minimal. The 4 and $11 \%$ salinity ponds had, also as expected, opposite responses. In the $4 \%$ pond, an increase in zooplankton slightly decreased bacterial abundance but consistently increased production and growth rate. Conversely, in the $11 \%$ pond, zooplankton concentration increased prokaryotic abundance, probably by depleting the bacterivore protists, and decreased production and growth rate. Bacteria in the lower salinity pond seemed not to be directly dependent on grazer pressure. In the intermediate pond, grazers seemed to control bacterial abundances and rates of growth, and in the $22 \%$ salinity pond bacteria seemed to be independent of protist grazer presence. These results are mostly in accordance with what was expected from previous work (Guixa-Boixereu et al. 1996, Pedrós-Alió et al. 2000a) and give support to the idea that the salinity gradient provides ecosystems with rather different microbial food web structure and controls in close vicinity, making them useful systems in which to study trophic interactions and microbial ecology (Pedrós-Alió et al. 2000a, PedrósAlió 2003).

Unfortunately, we did not collect DNA in the experiment performed in the $4 \%$ salinity pond, precisely where we would have expected most changes in bacterial composition (Fig. 8). In the 2 other experiments (11 and $22 \%$ ), the changes in bacterial abundance and growth rates were not reflected in changes in the composition of the bacterial assemblages, as depicted by bacterial DGGE fingerprints (Fig. 7). The changes in biomass were probably too small in the experiment to generate detectable changes in community composition. This was clear in the $22 \%$ saltern (Fig. 8), but also in the $11 \%$ salinity saltern, where we would have expected some changes in community composition, given that other authors have found community variations after experimental reduction of the protist predation pressure in bottle (Suzuki 1999) or mesocosm (Jürgens et al. 1999, Langenheder \& Jürgens 2001, Gasol et al. 2002a) experiments. However, there are also reports showing no appreciable changes in community structure even after strong changes in bacterial biomass under different treatments (different temperatures, organic matter additions, e.g. Massana et al. 2001). Community structure seems to be fairly resilient.

\section{Summary}

Multi-pond solar salterns are useful tools for microbial ecology studies as they provide naturally contrasting environments in close vicinity. However, most of the studies carried out to date have been descriptive and very few have covered functional aspects (PedrósAlió 2003). Our data on prokaryotic abundance and their rates of growth confirm that strong changes occur in ponds of different salinities (Figs. 1-4). Several experiments provided evidence that prokaryotic growth in the lower salinity ponds appeared to be limited by the availability of organic carbon (Expts NA and $\mathrm{Z}$ ), while in the intermediate salinity ponds the organic matter limitation seemed to be replaced by a stronger predation limitation (Expts NA and Z). Neither organic matter limitation nor zooplankton predation pressure seemed to affect bacterial development in the higher salinity ponds. Our initial hypotheses 
were in part confirmed but had to be adjusted: the lower salinity communities appeared to be limited by organic carbon and not strongly by predation pressure, which probably stimulated bacterial growth indirectly (Fig. 8). Thus, it was similar to Wright's (1984) type (2): an 'Active, substrate-limited' community, with relatively high abundances and specific activities, with low rates of growth after predators had been removed. This conclusion is, however, in part hampered by the lack of success in separating zooplankton and generating a correctly truncated trophic cascade in this experiment.

The middle salinity communities, with organic nutrient limitation of growth, but clear effect of predators on bacterial abundances and growth (Fig. 8), appeared to be of Wright's type (1): an 'Active, grazer-controlled' community, with moderately large numbers, high specific activity, and showing large bacterial growth when predation is experimentally reduced. For the crystallizer communities we expected Wright's type (3) communities: a 'Dormant, substrate-limited' community, with low cell-specific activities and no significant increases after elimination of predators. We observed some indications that this was the case, but we could not confirm our hypothesis because the dilution manipulation produced unexpected detrimental effects on the organisms, decreasing the contribution of the haloarchaea (Fig. 6), which were essential contributors to the total activity in such salinities (Fig. 3). In the $37 \%$ salinity pond, prokaryotes seemed to grow faster with dilution (except at the maximal dilutions) but their abundance decreased greatly, indicating perhaps that dilution was detrimental to some of the organisms (i.e. Archaea whereas Bacteria would be favored), an idea that would be supported by the changes in the \% inhibition with Tchl.

Differences in the taxonomic composition (Benlloch et al. 2002, Casamayor et al. 2002) and in the food web structure (Figs. 1 to 4, and data in Joint et al. 2002 and Estrada et al. unpubl.) were present in the different microbial communities developing at differing salinities along the gradient generated by water evaporation. Our results suggest that different mechanisms operated to determine prokaryotic abundances and rates of growth at different salinities. Thus, functional aspects of the microbial food web changed in accordance with the physical setting.

Acknowledgements. This study was supported by EU contract MIDAS MAS3-CT97-0154. Final preparation of the ms was supported by EU contract BASICS (EVK3-CT-200200078) and MCYT project MICRODIFF (REN2001-2120/ MAR). We thank Mr. Miguel Cuervo-Arango for permission to work at Bras del Port salterns and Isabel Casamajor for the zooplankton counts. We are indebted to F. Rodríguez-Valera for providing the facilities necessary to work at the Universidad Miguel Hernández and the Santa Pola salterns.

\section{LITERATURE CITED}

Antón J, Llobet-Brossa E, Rodríguez-Valera F, Amann R (1999) Fluorescence in situ hybridization analysis of the prokaryotic community inhabiting crystallizer ponds. Environ Microbiol 1:517-523

Antón J, Rosselló-Mora R, Rodríguez-Valera F, Amann R (2000) Extremely halophilic Bacteria in crystallizer ponds from solar salterns. Appl Environ Microbiol 66:3052-3057

Bell R (1993) Estimating production of heterotrophic bacterioplankton via incorporation of tritiated thymidine. In: Kemp PF, Sherr BF, Sherr EB, Cole JJ (eds) Handbook of methods of aquatic microbial ecology. Lewis Publishers, Boca Raton, FL, p 495-503

Benlloch S, Martínez-Murcia AJ, Rodríguez-Valera F (1995) Sequencing of bacterial and archaeal 16S rRNA genes directly amplified from a hypersaline environment. Syst Appl Microbiol 18:574-581

Benlloch S, López-López A, Casamayor EO, Øvreås L and 8 others (2002) Prokaryotic genetic diversity throughout the salinity gradient of a coastal solar saltern. Environ Microbiol 4:349-360

Casamayor EO, Calderón-Paz JI, Pedrós-Alió C (2000) 5S rRNA fingerprints of marine bacteria, halophilic archaea and natural prokaryotic assemblages along a salinity gradient. FEMS Microbiol Ecol 34:113-119

Casamayor EO, Mas J, Pedrós-Alió C (2001) In situ assessment on the physiological state of purple and green sulfur bacteria through the analyses of pigment and 5S rRNA content. Microb Ecol 42:427-437

Casamayor EO, Massana R, Benlloch S, Øvreås L and 6 others (2002) Changes in archaeal, bacterial and eukaryal assemblages along a salinity gradient by comparison of genetic fingerprinting methods in a multi-pond solar saltern. Environ Microbiol 4:338-348

Chin-Leo G, Kirchman DL (1990) Unbalanced growth in natural assemblages of marine bacterioplankton. Mar Ecol Prog Ser 63:1-8

Garland JL, Mills AL (1991) Classification and characterisation of heterotropic microbial communities on the basis of patterns of community-level sole-carbon-sources utilisation. Appl Environ Microbiol 57:2351-2359

Gasol JM, del Giorgio PA (2000) Using flow cytometry for counting natural planktonic bacteria and understanding the structure of planktonic bacterial communities. Sci Mar 64:197-224

Gasol JM, Zweifel UL, Peters F, Fuhrman JA, Hagström ^ (1999) Significance of size and nucleic acid content heterogeneity as measured by flow cytometry in natural planktonic bacteria. Appl Environ Microbiol 65:4475-4483

Gasol JM, Comerma M, García JC, Armengol J, Casamayor EO, Kojecká P, Šimek K (2002a) A transplant experiment to identify the factors controlling bacterial abundance, activity, production, and community composition in a eutrophic canyon-shaped reservoir. Limnol Oceanogr 47:62-77

Gasol JM, Pedrós-Alió C, Vaqué D (2002b) Regulation of bacterial assemblages in oligotrophic plankton systems: results from experimental and empirical methods. Antonie Leeuwenhoek 81:435-452

Guillard RRL (1975) Culture of phytoplankton for feeding marine invertebrates. In: Smith WL, Chauley HH (eds) Culture of marine invertebrate animals. Plenum Press, New York, p 108-132

Guixa-Boixereu N, Calderón-Paz JI, Heldal M, Bratbak G, Pedrós-Alió C (1996) Viral lysis and bacterivory as prokaryotic loss factors along a salinity gradient. Aquat Microb Ecol 11:215-227 
Haslett SJ, Wear RG (1985) Biomass estimation of Artemia at Lake Grassmere, Marlborough, New Zealand. Aust J Mar Freshw Res 36:537-557

Joint I, Henriksen P, Garde K, Riemann B (2002) Primary production, nutrient assimilation and microzooplankton grazing along a hypersaline gradient. FEMS Microbiol Ecol 39:245-257

Jürgens K, Pernthaler J, Schalla S, Amann R (1999) Morphological and compositional changes in a planktonic bacterial community in response to enhanced protozoan grazing. Appl Environ Microbiol 65:1241-1250

Kamekura M, Oesterhelt D, Wallace R, Anderson P, Kushner DJ (1988) Lysis of halobacteria in bacto-peptone by bile acids. Appl Environ Microbiol 54:990-995

Kirchman DL (1993) Leucine incorporation as a measure of biomass production by heterotrophic bacteria. In: Kemp PF, Sherr BF, Sherr EB, Cole JJ (eds) Handbook of methods of aquatic microbial ecology. Lewis Publishers, Boca Raton, FL, 509-512

Kirschner AKT, Eiler A, Zechmeister TC, Velimirov B, Herzig A, Mach R, Farnleitner AH (2002) Extremely productive microbial communities in shallow saline pools respond immediately to changing meteorological conditions. Environ Microbiol 4:546-555

Langenheder S, Jürgens K (2001) Regulation of bacterial biomass and community structure by metazoan and protozoan predation. Limnol Oceanogr 46:121-134

Lebaron P, Servais P, Agogué H, Courties C, Joux F (2001) Does the high nucleic acid content of individual bacterial cells allow us to discriminate between active cells and inactive cells in aquatic systems? Appl Environ Microbiol 67:1775-1782

Massana R, Pedrós-Alió C, Casamayor EO, Gasol JM (2001) Changes in marine bacterioplankton phylogenetic composition during incubations designed to measure biogeochemically significant parameters. Limnol Oceanogr 46: $1181-1188$

McCauley E (1984) The estimation of the abundance and biomass of zooplankton in samples. In: Downing J, Rigler FH (eds) A manual of methods for the assessment of secondary productivity in freshwaters. International Biological Program Handbook 17, Blackwell Scientific Publications, Oxford, p 228-265

Norland S (1993) The relationship between biomass and volume of bacteria. In: Kemp PF, Sherr BF, Sherr EB, Cole JJ (eds) Handbook of methods of aquatic microbial ecology. Lewis Publishers, Boca Raton, FL, p 303-307

Oren A (1990a) The use of protein synthesis inhibitors in the estimation of the contribution of halophilic archaebacteria to bacterial activity in hypersaline environments. FEMS Microbiol Ecol 73:187-192

Oren A (1990b) Thymidine incorporation in saltern ponds of different salinities: estimation of in situ growth rates of

Editorial responsibility: Gerhard Herndl, Den Burg, Texel, The Netherlands halophilic archaeobacteria and eubacteria. Microb Ecol 19:43-51

Oren A (1999) Bioenergetic aspects of halophilism. Microb Molec Biol Rev 63:334-349

Oren A, Rodríguez-Valera F (2001) The contribution of halophilic Bacteria to the red coloration of saltern crystallizer ponds. FEMS Microbiol Ecol 36:123-130

Øvreås L, Daae FL, Torsvik V, Rodríguez-Valera F (2003) Characterization of microbial diversity in hypersaline environments by melting profiles and reassociation kinetics in combination with terminal restriction fragment length polymorphism (T-RFLP). Microb Ecol 46:291-301

Pedrós-Alió C (2003) Trophic ecology of solar salterns. In: Ventosa A (ed) Halophilic microorganisms. SpringerVerlag, Berlin, p 33-48

Pedrós-Alió C, Calderón-Paz JI, MacLean MH, Medina G, Marrasé C, Gasol JM, Guixa-Boixereu N (2000a) The microbial food web along salinity gradients. FEMS Microbiol Ecol 32:143-155

Pedrós-Alió C, Calderón-Paz JI, Gasol JM (2000b) Comparative analysis shows that bacterivory, not viral lysis, controls the abundance of heterotrophic prokaryotic plankton. FEMS Microbiol Ecol 32:157-165

Pfennig N, Trüper HG (1989) Anoxygenic phototrophic bacteria. In: Murray RGE, Brenner DJ, Bryant MP, Holt JG and 6 others (eds) Bergey's manual of systematic bacteriology, Vol 3, Section 18. Williams \& Wilkins, Baltimore, MD, p 1635-1653

Rodríguez-Valera F (1988) Characteristics and microbial ecology of hypersaline environments. In: Rodríguez-Valera F (ed) Halophilic Bacteria, Vol I. CRC Press, Boca Raton, FL, p 3-30

Sandaa RA, Skjoldal EF, Bratbak G (2003) Virioplankton community structure along a salinity gradient in a solar saltern. Extremophiles 7:347-351

Shi WY, Zusman DR (1995) Methionine inhibits developmental aggregation of Myxососcus xanthus by blocking the biosynthesis of s-adenosyl. J Bacteriol 177:5346-5349

Simon M, Azam F (1989) Protein content and protein synthesis rates of planktonic marine bacteria. Mar Ecol Prog Ser 51:201-213

Smith DC, Azam F (1992) A simple, economical method for measuring bacterial protein synthesis rates in seawater using ${ }^{3} \mathrm{H}$-leucine. Mar Microb Food Webs 6:107-114

Suzuki MT (1999) Effect of protistan bacterivory on coastal bacterioplankton diversity. Aquat Microb Ecol 20:261-272

Worm J, Gustavson K, Garde K, Borch NH, Søndergaard M (2001) Functional similarity of attached and free-living bacteria during freshwater phytoplankton blooms. Aquat Microb Ecol 25:103-111

Wright RT (1984) Dynamics of pools of dissolved organic matter. In: Hobbie JE, Williams PJLeB (eds) Heterotrophic activity in the sea. Plenum Press, New York, p 121-154

Submitted: April 12, 2003; Accepted: October 16, 2003

Proofs received from author(s): January 14, 2004 